\title{
KONSTRUKSI PEMBERITAAN KAMPANYE PEMILIHAN WALIKOTA MEDAN TAHUN 2015 PADA SURAT KABAR ANALISA
}

\author{
TM. Saddam Amar \\ Universitas Sumatera Utara \\ tengkumhdsaddam@yahoo.co.id
}

\begin{abstract}
Abstrak
Penelitian ini bertujuan untuk melihat bentuk konstruksi berita kampanye, faktor-faktor yang mempengaruhinya, serta posisi media berita kampanye Walikota Medan tahun 2015 pada surat kabar Analisa. Penelitian ini bersifat deskriptif kualitatif dengan metode analisis framing Zhongdang Pan dan Gerald M. Kosicki. Fokus penelitian ini yaitu; sintaksis, skrip, tematik, dan retoris. Pengumpulan data dilakukan dengan cara melakukan kliping berita tentang pemberitaan Pemilihan Walikota Medan tahun 2015 pada masa kampanye (27 Agustus-5 Desember 2015). Penelitian ini mengungkap bentuk konstruksi berita kampanye Pilkada Kota Medan tahun 2015 pada surat kabar Analisa dikatakan lebih berimbang dalam memberitakan kedua pasang kandidat calon Walikota dan Wakil Walikota Medan tahun 2015 dan berusaha untuk independen, bebas tanpa tekanan untuk memberitakan suatu peristiwa. Selain itu, konstruksi berita kampanye dipengaruhi oleh faktor internal dan eksternal surat kabar Analisa. Hal ini menunjukkan bahwa netralitas dan objektivitas media dipengaruhi oleh kepentingan pemilik media. Selanjutnya, posisi media berita kampanye yang digunakan kedua kandidat pasangan calon Walikota dan Wakil Walikota Medan pada surat kabar Analisa cenderung dipandang sebagai media massa paling penting oleh semua calon Walikota, mengingat kedua pasangan calon melakukan kunjungan bergantian hari menemui Pimpinan surat kabar Analisa Supandi Kusuma.
\end{abstract}

Kata Kunci: konstruksi berita, analisis framing, kampanye.

\begin{abstract}
This study aims to determine the construction of campaign news, the factors that influenced it, and the news media position of Medan city Mayor campaign in 2015 in daily newspaper Analisa. This research is a qualitative descriptive study that used framing analysis method by Zhongdang Pan and Gerald M. Kosicki. The focus of this research are; syntax, script, thematic, and rhetorical. Data were collected by doing news clippings about Medan City Mayor Election in 2015 during the campaign period (27 August - 5 December 2015). The study reveals that that construction of the news about the election tends to try to be independent and balance in reporting the events. Besides, the news construction is influenced by internal and external factors of the newspaper. This showed that neutrality and objectivity is influenced by the interest of media owners. Furthermore, the position of news media that is used by both candidate pairs of Medan city Mayor 2015 in Analisa newspaper, tends to be seen as the most important mass media. This can be shown when the candidates respectively visited the leader of Analisa nespaper, Supand Kusuma.
\end{abstract}

Keywords: construction news, analysis framing, campaign

\section{PENDAHULUAN}

Salah satu produk dari demokratisasi adalah dikeluarkannya Undang-Undang Nomor 23 Tahun 2014 tentang Pemerintahan Daerah dan Undang-Undang Nomor 22 Tahun 2014 tentang Pemilihan Gubernur, Bupati, dan Walikota. Regulasi ini memandatkan dilaksanakannya pemilihan Gubernur dan Wakil Gubernur, Bupati dan Wakil Bupati serta Walikota dan Wakil Walikota secara langsung oleh rakyat, lewat apa yang kita kenal dengan pemilihan kepala daerah secara langsung (Pilkada). 
Pada pelaksanaan Pilkada Gubernur, Bupati, dan Walikota, semua kandidat berkepentingan untuk dapat tampil sebagai pemenang dalam memperebutkan suara terbanyak dalam pesta demokrasi. Berbagai upaya dan sarana serta celah yang ada, ditempuh kandidat bersama tim sukses untuk menarik perhatian, dukungan dan yang terutama adalah suara pemilih.

Kampanye merupakan media komunikasi politik kandidat bersama tim sukses untuk menyampaikan program dan pesan, yang selanjutnya dapat menarik perhatian pemilih. Bentuk kampanye sendiri sesuai dengan aturan yang ditetapkan oleh Komisi Pemilihan Umum (KPU), yakni pada Peraturan KPU Nomor 7 Tahun 2015 tentang Kampanye Pemilihan Gubernur dan Wakil Gubernur, Bupati dan Wakil Bupati, dan/atau Walikota dan Wakil Walikota adalah kampanye terbuka dan kampanye lewat media massa.

Kampanye melalui media massa yang dilakukan kandidat bersama tim sukses berupaya menyampaikan pesan dan membangun pencitraan diri untuk menarik simpati serta dukungan pemilih. Ruang publik di dalam media massa, menjadi ruang ekspresi yang tak lepas dari berbagai manuver, taktik, dan strategi politik yang digelar oleh elite politik dalam meraih dukungan atau suksesi pilkada. Teknik pencitraan politik dengan mengemas citra tentang sosok calon kepala daerah dalam praktik politik pencitraan (politics of image), menempatkan media massa sebagai kendali utama pemberitaan.

Penyampaian sebuah berita ternyata menyimpan subjektivitas penulis berita. Bagi masyarakat biasa, pesan dari sebuah berita akan dinilai apa adanya. Berita akan dipandang sebagai objektivitas. Berbeda dengan kalangan tertentu yang memahami betul gerak pers. Mereka akan menilai lebih "dalam" terhadap pemberitaan, yaitu dalam setiap penulisan berita menyimpan latar belakang. Seorang penulis akan memasukan ide-ide mereka dalam analisis. Berita atau pesan yang ditampilkan oleh media sering kali dimaknai apa adanya oleh masyarakat, artinya masyarakat lebih terpengaruh pada judul berita (headline) yang dimunculkan dan kesannya disimpulkan oleh media massa dari pada menganalisis secara mendalam teks berita tersebut. Kenyataannya sering terjadi kegagalan informasi dan kegagalan interpretasi antara apa yang seharusnya disampaikan dan kenyataan yang diterima oleh pembaca.

Masing-masing media ataupun penulis berita memiliki pandangan ideologis yang berbeda-beda terhadap suatu realitas/peristiwa maupun pemberitaan yang terjadi, maka diperlukan sebuah analisis terhadap isi berita, sehingga akan diketahui seorang penulis berita dan media massa dalam menulis berita. Analisis yang sesuai untuk mengungkapkan isi berita yaitu analisis framing. Analisis framing digunakan untuk mengetahui realitas (peristiwa) yang dikonstruksi oleh media. Sebuah realitas/peristiwa dikonstruksi dalam pemberitaan, karena masing-masing media pasti akan memberikan sikap mendukung, baik positif atau negatif yang merupakan efek dari bingkai yang dikembangkan oleh media.

Media, khususnya surat kabar, dapat menyajikan sebuah realitas/peristiwa yang sama, namun dalam hal mengkontruksi dan memahami sebuah peristiwa berbeda.

Analisis framing, yang dilihat adalah cara media memaknai, memahami, dan membingkai kasus/peristiwa yang diberitakan. Analisis framing menunjukkan aspek-aspek struktur dan bahasa berita yang mempengaruhi aspek-aspek yang lainnya. Penelitian framing, yang menjadi titik persoalan adalah realitas/peristiwa dikonstruksi dan dikembangkan oleh media (Eriyanto, 2006:7).

Media massa dalam kegiatan jurnalistiknya meliput suatu peristiwa untuk dijadikan berita/informasi yang akan dikonsumsi oleh masyarakat. Pada hakikatnya, berita itu sendiri merupakan laporan atas peristiwa. Laporan tersebut merupakan hasil dari mengkonstruksi fakta menjadi berita (konstruksi realitas). Konstruksi sosial pada media cetak mencakup pada pengaturan katakata membentuk frase, atau klausa yang 
bemakna untuk menjelaskan suatu kualitas keadaan aktual, benar, atau nyata dan dipublikasikan di media cetak (Hamad, 2004:4-6).

Pembuatan liputan berita politik yang memiliki dimensi pembentukan opini publik media massa umumnya melakukan tiga kegiatan sekaligus yang dipakai untuk mengkonstruksi realitas. Pertama, menggunakan simbol-simbol politik (langue of politic), kedua, melaksanakan strategi pengemasan pesan (framing strategies), ketiga, melakukan fungsi agenda setting media (agenda setting function). Ketika tiga tindakan tersebut dilakukan oleh sebuah media dipengaruhi oleh berbagai faktor internal berupa kebijakan redaksional tertentu mengenai suatu kekuatan politik, kepentingan politik para pengelola media, relasi media dengan sebuah kekuatan politik tertentu, dan faktor eksternal seperti tekanan pasar pembaca atau pemirsa, sistem politik yang berlaku, dan kekuatan-kekuatan luar lainnya. Dengan demikian boleh jadi satu peristiwa politik bisa menimbulkan opini publik yang berbeda-beda tergantung dari cara masing-masing media mengkonstruksi berita politik (Hamad, 2004:12).

Terbatasnya waktu kampanye yang disediakan oleh KPU, memaksa pasangan calon kepala daerah beserta tim kampanyenya untuk merencanakan strategi kampanye politik secara efektif agar dapat menjangkau seluruh masyarakat di daerah pemilihan. Jenis komunikasi yang dianggap sesuai untuk memenuhi kebutuhan itu menurut Mc Quail (1983) adalah komunikasi massa, sehingga saluran komunikasi yang paling banyak digunakan dalam kampanye politik adalah media massa. Media massa dipilih karena memiliki kekuatan untuk menjangkau khalayaknya secara luas dan serentak (Hamad, 2004: 15).

Kesempatan seorang calon kepala daerah untuk memenangkan pemilihan secara langsung pun bergantung pada penggunaan beragam media massa dalam kampanye politik yang dilakukannya (Nimmo, 2004:48). Tim kampanye dari setiap pasangan calon kepala daerah akan berusaha menciptakan citra diri yang positif dari pasangan calon tersebut di mata masyarakat, sebab citra diri yang positif dan prestasi calon kepala daerah berpengaruh besar bagi pemilih pemula dalam menentukan pilihannya (Suryatna, 2007). Kelebihankelebihan tersebut harus dikemas dengan baik melalui kegiatan kampanye politik yang telah disiapkan secara matang, sehingga dapat dijadikan sebagai nilai jual bagi pasangan calon kepala daerah dan wakil kepala daerah yang mengikuti pemilihan umum.

Pemilihan Walikota Medan tahun 2015 tidak luput dari sorotan media khususnya media cetak. Perlu dipahami lebih lanjut bahwa dalam pemberitaan di Surat Kabar Analisa tentang Pilkada Kota Medan 2015 (Pemilihan Walikota dan Wakil Walikota Medan) pada rubrik "Kota" terdiri beberapa tahapan berita: (1) pemberitaan setelah penetapan pengumuman Calon Walikota (2) pada masa kampanye (3) pasca pemilihan Walikota. Pada penelitian ini, dalam memilih berita peneliti lebih fokus pada pemberitaan Hot News (berita hangat) pada masa kampanye di surat kabar Analisa.

Pada Pilkada Kota Medan Tahun 2015 terdapat puluhan media cetak lokal baik terbit harian ataupun mingguan memberitakan tentang pelaksanaan kampanye Pilkada Kota Medan, dari puluhan media lokal yang ada, media yang menjadi fokus penelitian, yakni, surat kabar Analisa. Media ini dipilih karena merupakan media lokal harian yang secara intensif menerbitkan berita-berita dan hasil liputan selama pelaksanaan Pilkada Kota Medan Tahun 2015 dan dinilai independen tidak partisipan dalam pemberitaan, dimana pemberitaan media cenderung cover both side (dua sisi) dan mengakomodir pernyataan kedua kandidat pasangan calon Walikota dan Wakil Walikota dalam pilkada kota Medan tahun 2015. Sehingga masyarakat mendapat informasi yang benar dan tidak diarahkan untuk membentuk sentimen tertentu. Berangkat dari dinamika rubrik kota yang ada di surat kabar tersebut dalam memberitakan 
kampanye Pilkada Kota Medan tahun 2015, maka penulis tertarik untuk melakukan penelitian tentang Konstruksi Pemberitaan Kampanye Pemilihan Walikota Medan pada surat kabar Analisa.

\section{METODOLOGIPENELITIAN}

Penelitian ini merupakan suatu penelitian kualitatif, berupa analisa terhadap konstruksi berita kampanye pilkada Kota Medan tahun 2015 pada surat kabar Analisa. Jenis penelitian ini merupakan penelitian kualitatif deskriptif, yakni peneliti ingin mendeskripsikan surat kabar Analisa mengkronstruksi berita-berita kandidat Walikota dan Wakil Walikota Medan 2015 dan juga mendeskripsikan faktor-faktor yang mempengaruhi konstruksi berita kampanye pilkada Kota Medan tahun 2015 serta mendeskripsikan posisi media berita kampanye pilkada Kota Medan tahun 2015. Peneliti mengumpulkan teks berita kedua kandidat, kemudian dianalisis.

Dalam penelitian ini media yang dilteliti adalah Surat Kabar Analisa dalam pemberitaan pasangan kandidat calon Walikota Medan 2015 periode 18 Juli sampai 5 Desember 2015. Peneliti menentukan tema berita yang akan di analisis yakni pemberitaan hot news (berita hangat) pada masa kampanye di surat kabar Analisa tanggal 27 Agustus hingga 5 Desember 2015. Berdasarkan tema tersebut, peneliti mensortir beberapa berita yang mewakili "kegiatan dan program" dari masing-masing kandidat, total ada 6 berita, 3 berita pasangan BENAR dan 3 berita pasangan REDI.

Setelah dilakukan analisis teks berita, peneliti melakukan wawancara terhadap redaktur media untuk mengetahui lebih dalam pembingkaian berita yang dilakukan. Kemudidan dari hasil analisis berita dan hasil wawancara ditarik kesimpulan tentang bentuk konstruksi berita, faktor-faktor yang mempengaruhi konstruksi berita serta posisi media berita kampanye pilkada Kota Medan tahun 2015 pada surat kabar Analisa yang termaktub dalam perumusan masalah yang diamati.

\section{HASIL DAN PEMBAHASAN}

Mencermati konstruksi berita kampanye pemilihan kepala daerah Kota Medan dengan menggunakan Analisis Framing Zhongdang Pan dan Gerald M. Kosicki. Model ini berasumsi bahwa setiap berita mempunyai frame yang berfungsi sebagai pusat dari organisasi ide. Frame adalah suatu ide yang dihubungkan dengan elemen yang berbeda dalam teks berita (seperti kutipan sumber, latar informasi, pemakaian kata atau kalimat tertentu) ke dalam teks secara keseluruhan. Frame berhubungan dengan makna yang berdasarkan perangkat tanda dimunculkan dalam teks sehingga seseorang dapat memaknai suatu peristiwa.

Dalam penelitian ini, peneliti melakukan analisis framing pada berita headline tentang kampanye Walikota Medan tahun 2015 di surat kabar Analisa. Dari analisis data ang dilakukan, maka didapat hasil sebagai berikut.

\section{Struktur Sintaksis surat kabar Analisa pada pemberitaan kampanye Walikota Medan tahun 2015}

Bentuk sintaksis yang paling banyak digunakan adalah piramida terbalik yang dimulai dengan judul, lead, episode, latar, dan penutup. Unit yang diamati adalah judul, lead, informasi, kutipan, dan penutup. Menurut peneliti, Surat kabar Analisa beberapa kali membuat judul yang menekankan makna tertentu lewat pemakaian tanda baca khusus. Terlihat pada judul pemberitaan kampanye Walikota Medan pada tahun 2015. Surat kabar Analisa juga selalu memberi anak judul atau subjudul utama dalam pemberitaan kampanye Walikota Medan pada tahun 2015. Judul pemberitaan tidak boleh melebihi 7 kata. Oleh karena itu, Surat kabar Analisa membuat anak judul untuk mendukung judul utama dan menggambarkan topik pemberitaan lebih jelas.

Lead merupakan paragraf pembuka dari sebuah media yang biasanya mengandung kepentingan lebih tinggi. Menurut peneliti, lead yang baik tidak hanya mendukung judul 
berita, namun memberikan sudut pandang berita. Sehingga, saat membaca lead, pembaca dapat mengetahui garis besar pembahasan berita tersebut. Dilihat dari lead yang dibuat Surat kabar Analisa dalam pemberitaan kampanye Walikota Medan pada tahun 2015, terdapat lead yang tidak mendeskripsikan judul, tidak mendukung judul, tetapi menjabarkan anak judul. Seperti lead pemberitaan kampanye Walikota Medan tanggal 23 November 2015. Lead-nya tidak bersinggungan dengan judul utama. Lead yang baik juga mengandung unsur $5 \mathrm{~W}+1 \mathrm{H}$.

Menurut peneliti, tidak semua lead dalam setiap pemberitaan kampanye Walikota Medan pada tahun 2015 yang disajikan Surat kabar Analisa mengandung unsur tersebut dengan lengkap. Surat kabar Analisa dalam pemberitaan mencantumkan unsur who, what, where, dan when. Sedangkan unsur why dan how tidak selalu terdapat dalam setiap berita, yang paling menonjol adalah unsur who dan what.

Bagian berita lain yang penting diperhatikan adalah pengutipan sumber berita. Bagian ini sering dimaksudkan untuk menampakkan objektivitas. Surat kabar Analisa selalu mengutip sumber yang relevan untuk menampakkan kebenaran dalam ulasan beritanya. Kutipannya juga terkadang menghubungkan pernyataan sumber satu dengan sumber lain sebagai pendukung atau penguat pernyataan sumber sebelumnya. Surat kabar Analisa menuliskan pemberitaan yang didalamnya terdapat pandangan tentang sosok calon Walikota salah satunya berita tanggal 23 November 2015.

Pada pemberitaan hari itu, Surat kabar Analisa mengutip pernyataan Mantan Gubernur Sumatera Utara mengenai kandidat pasangan Dzulmi Eldin dan Akhyar Nasution (BENAR). Tidak hanya berita untuk pasangan BENAR, surat kabar Analisa juga menyajikan pernyataan untuk pasangan Ramadhan Pohan dan Eddie Kusuma (REDI) pada berita tanggal 18 November 2015. Surat kabar Analisa memperlihatkan keberimbangan dalam menyajikan informasi kedua pasangan calon Walikota dan Wakil Walikota.

Dilihat dari judul berita kampanye Walikota Medan pada tanggal 27 Agustus hingga 5 Desember 2015, Surat kabar Analisa terkadang menggunakan kata-kata provokatif. Seperti berita tanggal 22 November 2015 dengan judul "Anak Medan Pilih Orang Medan Asli" yang dimaksudkan untuk pasangan BENAR begitu juga dengan pemberitaan kampanye untuk pasangan REDI pada tanggal 18 November 2015 dengan judul "Pemuda Deli Berpaling ke REDI".

Menurut peneliti, hal tersebut yang membuat pemberitaan yang disajikan Surat kabar Analisa lebih mengarah pada ketertarikan pembaca untuk membaca berita tersebut dan pada akhirnya dapat menentukan pilihan untuk memilih pasangan calon Walikota dan Wakil Walikota yang bertarung pada pemilihan kepala darah tahun 2015.

Seperti yang dikemukan Bennet (1982), media dipandang sebagai agen konstruksi sosial yang secara aktif mendefinisikan realitas untuk disajikan kepada khalayak. Media memilih realitas mana yang dipakai dan yang tidak dipakai. Surat kabar Analisa ingin menggiring khalayak pada perspektif citra program kandidat calon Walikota dan Wakil Walikota Medan tahun 2015.

\section{Unsur Skrip Surat kabar Analisa pada pemeberitaan kampanye Walikota Medan tahun 2015}

Surat kabar Analisa mengakali minimnya data dengan memasukan lebih banyak sumber untuk dikutip keterangannya. Menurut peneliti, cara tersebut merupakan alternatif yang tepat untuk menyajikan berita kampanye Walikota Medan pada tahun 2015. Karena data yang masih simpang siur akan sangat berisiko jika dipublikasikan tanpa menyertakan sumber yang memberi informasi tersebut.

\section{Struktur Tematik Surat kabar Analisa pada pemeberitaan kampanye Walikota Medan tahun 2015}

Struktur tematik dapat diamati dari peristiwa itu diungkapkan atau dibuat oleh wartawan. Struktur tematik berhubungan 
dengan fakta yang ditulis. Kalimat yang dipakai, penempatan dan penelitian sumber ke dalam teks berita secara keseluruhan. Berita seringkali memfokuskan pemberitaan pada aktor tertentu. Hal ini tentu saja tidak salah. Tetapi, efek yang segera terlihat adalah memfokuskan pada satu pihak atau aktor tertentu menyebabkan aktor lain yang mungkin relevan dan penting dalam pemberitaan menjadi tersembunyi.

Surat kabar Analisa pada berita kampanye Walikota Medan pada tahun 2015 tersebut, tema yang banyak dibanyak diangkat adalah tema citra program kandidat calon Walikota dan Wakil Walikota. Tema ini mengandung nilai human interest yang dapat menyentuh perasaan pembacanya melalui pemberitaan kejadian yang mengandung simpati, tragedi, dan kesedihan.

Tema citra program kandidat yang sering disorot membawa sisi ini menjadi sisi yang paling menonjolkan. Terutama di saat Surat kabar Analisa menuliskan programprogram dalam pembanguna kota Medan lima tahun mendatang yang akan dilaksanakan masing-masing kandidat. Perkembangannya terus mewarnai pemberitaan, baik menjadi berita utama maupun menjadi subjudul yang menambah informasi berita.

\section{Struktur retoris Surat kabar Analisa pada pemeberitaan kampanye Walikota Medan tahun 2015}

Struktur retoris dari wacana berita menggambarkan pilihan gaya atau kata yang dipilih oleh wartawan untuk menekankan arti yang ingin ditonjolkan oleh wartawan. Selain lewat kata, penekanan pesan dalam berita juga dapat dilakukan dengan menggunakan grafis. Elemen grafis muncul dalam bentuk foto, gambar, dan tabel untuk mendukung gagasan atau untuk bagian lain yang tidak ingin ditonjolkan. Berdasarkan struktur retoris harian Surat kabar Analisa di atas, penggunaan tanda baca tertentu dalam pemilihan kata tertentu, lebih menonjolkan makna yang digambarkan wartawan. Penambahan tanda baca seperti tanda petik (“") akan menambah penekanan makna pada kata ataupun frase yang ditulis.

Selain lewat kata, penekanan pesan dalam berita juga dapat dilakukan dengan menggunakan unsur grafis. Elemen grafis muncul dalam bentuk foto, gambar, dan tabel untuk mendukung gagasan atau bagian lain yang tidak ingin ditonjolkon. Elemen grafis yang paling kuat dalam pemberitaan kampanye Walikota Medan pada tahun 2015 menampilkan elemen grafis dalam berita berupa foto. Momen penting bagi media untuk menampilkan berita yang paling menarik pembaca. Tidak hanya dari isi beritanya, penambahan elemen grafis akan menaikkan nilai pemberitaan. Surat kabar Analisa juga tidak ingin melewatkannya dalam pemberitaan kampanye Walikota Medan.

Narasi yang dibangun dan dipoles sedemikian rupa dengan bahasa, tidak sekedar untuk melukiskan suatu fenomena atau lingkungan, tetapi juga dapat mempengaruhi cara melihat lingkungan kita. Implikasinya, bahasa juga dapat digunakan untuk memberikan akses tertentu terhadap suatu peristiwa atau tindakan, misalnya dengan menekankan, mempertajam, memperlembut, mengagungkan, melecehkan, membelokkan, atau mengaburkan peristiwa atau tindakan tersebut.

Dalam dunia pencitraan, citra dan realitas menjadi dua kutub yang terus tarik menarik. Citra telah berubah menjadi sebuah mesin politis yang bergerak kian cepat. Strategi pencitraan dan teknologi pencitraan atau imagologi dikemas sedemikian rupa untuk mempengaruhi persepsi, emosi, perasaan, kesadaran, dan opini publik sehingga mereka dapat digiring ke sebuah preferensi, pilihan dan keputusan politik tertentu.

Citra politik menjelma menjadi "kekuatan utama" dalam mengendalikan wacana politik sehingga di dalamnya kini tidak hanya ada kekuatan pengetahuan, tetapi lebih penting lagi menjelmanya "kekuatan citra" (power/image) sebagai kekuatan politik. Meskipun pada akhirnya pemberitaan media menunjukkan sifat netral atau berpihak, 
merepresentasikan fakta atau rekayasa fakta, menggambarkan realitas atau hanya mensimulasi realitas. Namun yang jelas media tidak dapat dilepaskan dari berbagai kepentingan, baik itu kepentingan ekomomi maupun kepentingan ideologi.

\section{KESIMPULAN}

Hasil penelitian ini didapat bahwa surat kabar Analisa dapat dikatakan lebih berimbang dalam memberitakan kedua pasang kandidat calon Walikota dan Wakil Walikota Medan tahun 2015. Surat kabar Analisa tidak hanya memberitakan keunggulan kedua kandidat, tetapi juga kelemahan keduanya.

Meskipun surat kabar Analisa berusaha untuk berimbang, namun tidak dapat dipungkiri terdapat satu berita yang cenderung kurang berimbang. Meskipun begitu, surat kabar Analisa dapat dikatakan independen karena surat kabar Analisa tidak mendapat tekanan, terutama dari pemilik media, karena tidak berafiliasi dengan partai politik tertentu. Sulit untuk mencapai media yang murni netral, yang ada adalah media yang berusaha untuk independen. Begitu banyak pertimbangan dalam mengkonstruksi pesan menjadi sebuah berita. Meskipun tidak bisa murni netral, surat kabar Analisa berusaha untuk independen, bebas tanpa tekanan untuk memberitakan suatu peristiwa.

Konstruksi berita surat kabar tentang kampanye Pilkada Kota Medan tahun 2015 dipengaruhi oleh faktor internal dan eksternal surat kabar Analisa. Framing yang dilakukan surat kabar Analisa terhadap pemberitaan kampanye pilkada Kota Medan tahun 2015 menunjukkan usaha media untuk melakukan pendekatan pada objektivitas pemberitaan.

Posisi media berita kampanye pilkada Kota Medan tahun 2015 yang di gunakan kedua kandidat pasangan calon Walikota dan Wakil Walikota Medan pada saurat kabar Analisa cenderung dipandang sebagai media massa paling penting oleh semua calon Walikota, mengingat kedua pasangan calon melakukan kunjungan bergantian hari menemui Pimpinan surat kabar Analisa Supandi Kusuma.

\section{DAFTAR PUSTAKA}

Anggoro, Ayub Dwi. (2014). Media, Politik dan Kekuasaan (Analisis Framing Model Robert N. Entman tentang pemberitaan hasil pemilihan Presiden, 9 Juli 2014 di TV One dan Metro TV). Jurnal Ilmu Sosial dan Ilmu Politik Universitas Muhammadiyah Ponorogo. Vol:2 Nomor 1. Agustus 2014.

Eriyanto. (2006). Analisis Wacana: Pengantar Analisis Teks Media. Yogyakarta: LKiS Pelangi Aksara

Hamad, Ibnu. (2004). Konstruksi Realitas Politik Dalam Media Massa: Sebuah Study Critical Discourse Analysis Terhadap Berita-berita Politik. Jakarta: Granit.

Nimmo, Dan. (2004). Komunikasi Politik: Komunikator, Pesan, dan Media. Bandung: PT. Remaja Rosdakarya.

Pratyaksa, I. G. \& Bharata. B. S.(2013). Bingkai Berita Pemilihan Gubernur Bali (Analisis Framing Berita Kampanye Pemilihan Gubernur Bali 2013-2018 pada Surat Kabar Harian Bali Post dan Surat Kabar Harian Fajar Bali Edisi 28 April 2013 - 11 Mei 2013). Jurnal Fakultas Ilmu Sosial dan Ilmu Politik Universitas Atma Jaya Yogyakarta.

Kadir, A., (2013). Peranan Partai Politik dalam Menanggulangi Golongan Putih (Golput) pada Pemilihan Legislatif 2009, Jurnal Ilmu Pemerintahan dan Sosial Politik, 1 (1): 65-75.

Suharyanto, A., (2014). Partisipasi Politik Masyarakat Tionghoa dalam Pemilihan Kepala Daerah, Jurnal Ilmu Pemerintahan dan Sosial Politik, 2 (2): 166-175

Harahap, A.A.H., \& Rosmala D., (2014). Pengaturan Calon Independen Pada Komisi Pemilihan Umum Daerah Kabupaten Padang Lawas, Jurnal Administrasi Publik Universitas Medan Area, 2 (2): 129-136 